\title{
Evaluation of composite blends of fermented fenugreek and wheat flour to assess its suitability for bread and biscuit
}

\author{
Atlaw Tamiru Kasaye ${ }^{1, ~ *, ~ Y o g e s h ~ K u m a r ~ J h a ~}{ }^{2}$ \\ ${ }^{1}$ Department of Food Science \& Postharvest Technology, College of Agriculture and Veterinary Medicine, Jimma University, Jimma, \\ Ethiopia \\ ${ }^{2}$ Food Process Engineering Program, School of Chemical and Bio Engineering, Addis Ababa Institute of Ethiopia, Addis Ababa University, \\ Addis Ababa, Ethiopia
}

Email address:

tamirukasaye514@gmail.com (A. T. Kasaye)

\section{To cite this article:}

Atlaw Tamiru Kasaye, Yogesh Kumar Jha. Evaluation of Composite Blends of Fermented Fenugreek and Wheat Flour to Assess Its Suitability for Bread and Biscuit. International Journal of Nutrition and Food Sciences. Vol. 4, No. 1, 2015, pp. 29-35.

doi: 10.11648/j.ijnfs.20150401.15

\begin{abstract}
Flour of fenugreek supplemented at 5, 10, and 15\% levels with wheat flour was assessed for the production of bread and biscuit to improve nutritional profile. Germinated fenugreek flour samples had $29.89 \%$ crude protein, $7.91 \%$ crude fat, $11.35 \%$ crude fiber and $2.94 \%$ ash on dry weight basis. The wet gluten, falling number, and water activity of wheat flour reduced on incorporation of germinated fenugreek flour while the foaming capacity, water and oil absorption increased for bread and biscuit blended wheat flours. The farinograph water absorption values were 66.3, 63.9 and 61.8\%, while the dough stability values were 7.0, 9.0 and $10.5 \mathrm{~min}$ at 5,10 and $15 \%$ supplementation levels, respectively. The dough development times were 4.5, 6.1, and $7.5 \mathrm{~min}$ and farinograph quality numbers were 76, 100 and 123 Brabender units, respectively. The microbiological analysis of value added products for coliforms, E.coli, and yeast was absent, and TPC and mould counts were lower than control. The nutritive values in terms of protein, fiber, ash as well as calcium, magnesium, iron and zinc content of bread and biscuit increased as a result of the supplementation of germinated fenugreek flour to wheat flour. The sensory evaluation of the bread samples made by supplementation at 5 and $10 \%$ and $5 \%$ levels for biscuit were rated acceptable.
\end{abstract}

Keywords: Composite Blends, Germinated Fenugreek Flour, Functional Properties, Farinograph Values, Nutritional Profile, Sensory Characteristics

\section{Introduction}

In developing countries with the increasing urbanization, the demand of processed food is increasing rapidly. There is urgent need for cheaper foods rich in protein for individuals, taking into consideration their age, sex, physical activity and physiological needs. Therefore, the need for strategic use of inexpensive high protein resources that complement the balanced amino acid profile of the staple diet in order to enhance their nutritive value and overcome malnutrition problem in developing countries (Addisu 2011). Among the processed foods, bakery products have wide popularity in rural as well as urban areas among all the age groups (Agrawal, 1990).

To augment the protein quality, the concept of cereallegume complementation by blending cereal and legume flours can be applied. Fortification with high protein legume flours could provide a good opportunity to improve the nutritional quality of protein consumed by many people. Therefore, fortification of wheat flour with non-wheat flour increasing the nutritional quality of wheat products by improving its amino acid profiles (Stark and Madar 1993).

Fenugreek (Trigonella foenum-graecum L.) is an annual legume mainly used as a spice crop in many parts of the world. This crop is native to an area extending from Iran to northern India, but is now widely cultivated in China, North and East Africa, Ukraine and Greece (Petropoulos 2002). It is locally used as a pulse, spice and medicinal plant, and has a long history in Ethiopia (Gall and Zerihun 2009).

Fenugreek seed can be utilized for value addition of 
cereals based food products to attain multiple benefits. It is used as a condiment and as a supplement to wheat and maize flour for bread making and as a constituent of the daily diet of general population in Indian subcontinent. It can be incorporated in to food products, such as cookies, cereals, crackers, doughnuts, bagels, biscuits, pizza dough, pasta, bread, juices, salads, sauces, and candies. Its leaves are consumed widely in India as a green leafy vegetable and are a rich source of calcium, iron, $\beta$-carotene and other vitamins (Sharma et al 1996).

In view of above, the present study has been planned to evaluate blends of fermented fenugreek and wheat flour and perform the physico-chemical, functional and nutritional characteristics to assess its suitability for bread and biscuit production.

\section{Materials and Methods}

Fenugreek seeds were obtained from Sinana Agricultural Research Center, Bale Robe, and Ethiopia. Both soft and hard wheat flour and ingredients were obtained from Kality Food Share Company, Ethiopia, currently producing bakery products at commercial scale.

Preparation of fenugreek flour: Fenugreek seeds were cleaned, graded, sorted and washed three times using potable water. Then, the seeds were soaked in potable water for $24 \mathrm{~h}$ at room temperature with seeds: water ratio of $1: 5(\mathrm{w} / \mathrm{v})$. The unimpeded water was discarded and the soaked seeds were rinsed twice by boiled cooled water to avoid post contamination during germination. The soaked seeds were germinated in plastic sieves covered with sterilized cloth for $72 \mathrm{~h}$ at room temp with frequent watering. The germinated fenugreek seeds were dried in a drying oven (BeschickungLoading, Model 100-800, Memmert, Germany) at $60^{\circ} \mathrm{C}$ for $24 \mathrm{~h}$ (Shalini \& Sudesh 2004) and ground to pass through 710 micron sieve (Endecotts LTD., London, UK) to obtain fine powder.

Blend formulation: The wheat flour was supplemented at 5, 10 , and $15 \%$ of dried germinated fenugreek flour. The flour blends were mixed using laboratory mixing machine (Model: R100C, CAT, Chicago, 1970). The flour mixtures were individually blended, homogenized, packed in polyethylene bags and stored at room temperature till further use. All formulated blends were analyzed for proximate composition (Moisture, total ash, fat, protein and fiber), physico-chemical analysis (Color grade value, falling number, wet gluten, water activity and farinograph values such as water absorption, stability, development time, degree of softening and farinograph quality number), functional properties (Bulk density, water absorption capacity, dispersibility, oil absorption capacity, foaming capacity) using standard methods Etana et al (2013).

Bread preparation: The bread samples made from three blend formulations and control flour were baked using straight dough method. The baking formula with $63 \%$ flour blend, $0.3 \%$ yeast, $0.3 \%$ bread improver, $0.6 \%$ salt and $35.8 \%$ water (Etana et al., 2013). All ingredients were mixed in a dough mixer (Model G.P.A. Orlandi mixer, Italy) for $15 \mathrm{~min}$.
The dough was fermented in a bowl covered with low density polyethylene for $30 \mathrm{~min}$ at room temp. It was then knocked back, molded and the dough pieces were then allowed to ferment for $60 \mathrm{~min}$ in a proofer at $35^{\circ} \mathrm{C}$ and $80 \%$ relative humidity. The fermented dough was baked at $213{ }^{\circ} \mathrm{C}$ for 20 min according to Shalini and Sudesh (2005).

Biscuit preparation: $65.1 \%$ flour blend with other ingredients (18.49\% sugar, 9.3\% shortening, 0.93\% skimmed milk powder, $1.86 \%$ high fructose, $0.37 \%$ sodium bicarbonate, $1.02 \%$ ammonium bicarbonate, $0.58 \%$ salt, $0.02 \%$ vanilla) were mixed with $2.33 \%$ water in to a mixing bowl for $15 \mathrm{~min}$ at high speed using a mixer (Model G.P.A. Orlandi mixer, Italy) (Hegazy and Ibrahim, 2009). The dough was removed from the mixer and allowed to keep at a normal room temperature for about 5-10 $\mathrm{min}$ to allow proper fermentation. Then fermented dough was placed in sheeting rollers so that it attains the proper thickness. The formed biscuits were baked in an electric convection oven (model G.P.A. Orlandi oven, Italy) at $170^{\circ} \mathrm{C}$ for $7 \mathrm{~min}$ (Hegazy and Ibrahim 2009).

Proximate composition analysis: Moisture content, total ash, crude fat, crude protein and crude fiber were determined by the methods described in AOAC (2000). Total carbohydrates of the samples including crude fiber were determined by difference. The minerals were determined by flame atomic absorption spectrometry and flame photometry as mentioned in AOAC (2000).

Functional properties analysis: Bulk density and Water absorbing capacity were determined by the methods used by Narayana and Narasinga-Rao (1984) and Helen (2011), respectively. Dispersibility, oil absorption capacity and foaming capacity were determined by the method used by Coffman and Gracia (1977).

Phsico-chemical analysis: Color grade value, falling number (Hag berg falling number apparatus, model 1500, Sweden, 2005), wet gluten content, water activity and farinograph values (water absorption, stability, development time, degree of softening and farinograph quality number) of control wheat flour and blends were measured by standard methods as described by Etana et al (2013).

Microbiological analysis: Total plate counts, yeast and mould, Coliforms and E. coli counts were enumerated in control, bread and biscuit samples supplemented with fenugreek flour by standard methods as described by Neilsen (2003).

Sensory evaluation of products: The sensory characteristics of biscuit and bread were evaluated by 20 trained sensory panels. The panelists were asked to evaluate color, appearance, taste, flavor, texture and overall acceptability of the samples on a 9-point hedonic scale, ranging from 9 as like extremely to 1 as dislike extremely (Meilgaard et al 2007).

Data analysis: The quality characteristics of flours, as well as the baking test results of products made with fenugreek flour supplementation were analyzed by one way ANOVA (Analysis of Variance) using statistical tools of JMP version 5 (SAS Institute Inc., Cary, NC, USA). Significance was accepted at 0.05 level of probability $(p \leq 0.05)$. Mean separation was performed by "Each pair student's t-test" for multiple comparison of means. 


\section{Results and Discussion}

Raw material analysis: The fenugreek flour had 29.89\% crude protein, $7.91 \%$ crude fat, $11.34 \%$ crude fiber, $51.55 \%$ carbohydrate and $2.94 \%$ ash content on dry weight basis. Fenugreek Seeds are a good source of minerals and had $168.88 \mathrm{mg} / 100 \mathrm{~g} \mathrm{Ca}, 153.10 \mathrm{mg} / 100 \mathrm{~g} \mathrm{Mg}, 11.51 \mathrm{~g} / 100 \mathrm{~g} \mathrm{Fe}$ and $4.43 \mathrm{mg} / 100 \mathrm{~g} \mathrm{Zn}$. It is revealed that hard wheat flour had $10.84 \%$ protein, $1.68 \%$ fat, $0.5 \%$ fiber and $1.84 \%$ ash content whereas soft wheat flour had $9.61 \%$ protein, $1.15 \%$ fat, $0.4 \%$ fiber and $1.06 \%$ ash content, used for bread and biscuit preparation in this investigation, respectively. Generally, fenugreek flour is highly nutritious as compared with wheat flour in terms of proximate composition and mineral content (Sharma et al 1996). Therefore, fenugreek seeds offer a logical means to upgrade the quantity and quality of protein and dietary fiber of wheat flours.

Physico-chemical properties of wheat flour and blended flours are shown in table 1 . The color grade values for the blended flours of both bread and biscuit were higher in comparison to control wheat flour which showed less bright flours. The highest color values (4.36 and 6.33) were observed for bread and biscuit flour samples supplemented with $15 \%$ germinated fenugreek flour, respectively. Low values of color grade are preferred value in producing white bread and biscuit. Hence, flour samples with 5\% for biscuit and up to $10 \%$ for bread production were most preferable. Both bread and biscuit wheat flour exhibited wet gluten contents of 32.9 and $23.5 \%$; respectively, which reduced upon supplementation with fenugreek flours at all levels where as on mean basis a non significant difference was observed among the blends. Shalini and Sudesh (2003) also reported that the wet gluten decreased in increasing the levels of non-wheat flour in wheat flour. The falling numbers of the blended flours were lower than the control wheat flour because fenugreek flour had higher amylase activity. The results showed significant variations among the treatments due to different level of supplementation which ranged from 222.0 to $293.7 \mathrm{sec}$ for bread production and 188.0 to 221.3 for biscuit production.

The water activity of blended flours used for bread and biscuit preparation ranged from 0.42 to 0.59 and 0.41 to 0.58 , respectively which were suitable for good condition storage by restricting the access to water and reducing the chemical change in the flour. As the supplementation level of fenugreek flour increased, the water activity decreased. The presenting findings are in confirmation with Bolandi et al (2008) who reported that the actual water activity of flours during storage ranged from 0.3 to 0.6 .

Table 2 depicts the functional properties of fenugreekwheat composite flour of biscuit and bread production. The bulk density of the flour samples ranged from $0.77-0.82$ $\mathrm{g} / \mathrm{cm}^{3}$ for biscuit and $0.81-0.83 \mathrm{~g} / \mathrm{cm}^{3}$ for bread. The bulk density is generally affected by the particle size and the density of flour and important in determining the packaging requirement, raw material handling and application in wet processing in the food industry (Ajanaku et al., 2012).
Nutritional profile of biscuits: The protein, ash, carbohydrate, fiber and mineral percent of biscuit samples increased as the supplementation level of germinated fenugreek flour increased in the blend. Highest protein $(12.67 \%)$ was recorded for biscuit prepared from wheat supplemented with $15 \%$ germinated fenugreek flour while the lowest $(9.66 \%)$ for control (Table 5). The crude fat content of samples ranged from 13.64 to $17.02 \%$. Biscuit with $15 \%$ fenugreek flour had higher ash content $(3.78 \%)$ where as lowest in the control. Similar results were reported by Hegazy and Ibrahim (2009) that incorporation of fenugreek flour to biscuits formula increased protein, fat, fiber, ash and amino acids contents. It is apparent that the supplementation of fenugreek flour to wheat flour significantly $(p<0.05)$ increased calcium, iron, zinc and magnesium percent in the bread and biscuit samples.

Physical characteristics of bread samples prepared from wheat and different fenugreek composite flours are presented in Table 6. Loaf volume is one of the major quality indicators for bread and is influenced by many factors including wheat flour compositions, additives and dough fermentation conditions (Rosell et al 2001). Significant reduction in loaf volume was observed at all the levels of supplementation. Maximum reduction in loaf volume $(334 \mathrm{ml})$ of the bread was observed in case of germinated fenugreek flour at $15 \%$ supplementation level. This may be due to the dilution effect on gluten content with the addition of non wheat flour to wheat flour that has been reported to be associated with loaf volume depression effect of composite flours as also reported by Sharma and Chauhan (2000). Other workers have also reported similar decrease in loaf volume of bread supplemented with non-wheat flours (Sharma and Chauhan, 2000). Loaf weight increased with the increase in the level of fenugreek flour in wheat flour. Loaf weight of control bread was 86.6 g. Supplementation of wheat flour with fenugreek flour at $15 \%$ level, a significant increase in loaf weight (94.73g) was observed, indicating that an extra amount of water was retained in breads after baking (Rao and Hemamalini 1991). The present results are in conformation with the findings of Sharma and Chauhan, (2000) that showed increase in loaf weight in fenugreek flour supplemented breads. Loaf weight increased with the increase in the level of fenugreek flour in wheat flour. Loaf weight of control bread was $86.6 \mathrm{~g}$. Supplementation of wheat flour with fenugreek flour at $15 \%$ level, a significant increase in loaf weight $(94.73 \mathrm{~g})$ was observed, indicating that an extra amount of water was retained in breads after baking (Rao and Hemamalini 1991). The present results are in conformation with the findings of Sharma and Chauhan (2000) that showed increase in loaf weight in fenugreek flour supplemented breads.

The physical characteristics of fenugreek based biscuits and control are shown in Table 6. Physical characteristics showed significant increase among the different blends compared to control accept spread ratio. Spread ratio of biscuits supplemented with different level of fenugreek flour and control samples ranged from 98.95 to 74.54 being highest in 
the control. Similarly other research worker also reported that incorporation of oat bran, soy flour, and black gram flour decreased the spread ratio (Mc Watters et al., 2003).

Sensory characteristics of bread: The crumb color of fenugreek flour supplemented bread, scored maximum points (7.97) for 5:95 followed by 10:90 (7.77) and lowest (5.04) being for 15: 85 blend as against 8.13 for the control sample. Color variations in bread crumb color due to supplementation of fenugreek flour at 5 and $10 \%$ were significant (Table 7). A decrease in crumb color intensity with the increase in the level of substitution of fenugreek flour also reported by Sharma and Chauhan (2000).

Aroma, the quality perceived by the sense of smell plays a primary role in creating consumer appeal. The aroma of fenugreek flour supplemented bread samples scored maximum (7.87) in 5:95 (bread with 5\% fenugreek flour) followed by 10:90 (7.53) and lowest (5.1) being for 15:85 blend and 7.76 in the control bread. Our findings are in support of Shalini and Sudesh (2004) who also observed better flavor in germinated fenugreek flour supplemented bread. Control bread samples rated significantly at par with the bread samples made from 5 and 10\% supplemented fenugreek flour. The bread samples supplemented with fenugreek flour at 5 and 10\% levels exhibited non-significant difference in taste and rated at par with control by sensory panels but noticed significant difference at $15 \%$ supplementation level. Appearance, Texture and Overall acceptability of bread samples made from blends of 5:95 and 10:90 are within acceptable limits. No significant differences were noticed with respect to control bread samples.

Sensory characterizes of biscuits: Biscuits supplemented by different levels of fenugreek flour and the control (wheat biscuit) samples were evaluated sensory characteristics. The mean scores of sensory attributes ranged between 4.40 and 8.46. Biscuit prepared with $100 \%$ of wheat flour scored maximum than the rest of the blends. The mean scores decreased as the proportion of fenugreek flour increased in the blends. The highest value was recorded for biscuit made with 5\% fenugreek flour while the lowest value was for $15 \%$ fenugreek flour with wheat flour. There were no significant difference among control sample and biscuits containing 5\% germinated fenugreek flour with respect to sensory characteristics.

Microbial profile: The microbial profile of fenugreek based bread and biscuit had lower counts than control samples (Table 8). This was due to fenugreek is reported to have anti-microbial and hypocholestrolemic activity (AlHabori and Raman 2002). According to WHO Standard (1994) the maximum permissible limits in baked products (cake, bread and biscuit) for Total plate count (TPC) is 2.0 $\mathrm{x} 10^{5} \mathrm{cfu}^{-1}$,coliforms bacteria $<20 \mathrm{cfu} \mathrm{g}^{-1,}$ E. coli absent, yeast and mold is $<1.0 \times 10^{4} \mathrm{cfu}^{-1}$. Thus, developed fenugreek based bread and biscuit had lower microbial profile (Table 8) compared to WHO Standards (1994).

Table 1. Physico-chemical properties of wheat flour and blended flours.

\begin{tabular}{|c|c|c|c|c|}
\hline \multirow{2}{*}{ Parameters } & \multicolumn{4}{|c|}{ Blends (FF:WF) for bread production } \\
\hline & $0: 100$ & $5: 95$ & 10:90 & $15: 85$ \\
\hline Color grade & $0.58 \pm 0.18^{\mathrm{a}}$ & $1.41 \pm 0.08^{b}$ & $2.40 \pm 0.10^{\mathrm{c}}$ & $4.36 \pm 0.21^{\mathrm{d}}$ \\
\hline Wet gluten $(\%)$ & $32.9 \pm 0.44^{\mathrm{a}}$ & $30.37 \pm 0.40^{\mathrm{a}}$ & $28.3 \pm 0.20^{\mathrm{a}}$ & $26.6 \pm 0.25^{\mathrm{a}}$ \\
\hline Falling number (sec.) & $293.7 \pm 0.58^{\mathrm{a}}$ & $288.0 \pm 1.00^{\mathrm{b}}$ & $257.7 \pm 1.53^{\mathrm{c}}$ & $222.0 \pm 1.00^{\mathrm{d}}$ \\
\hline Water activity $\left(\mathrm{a}_{\mathrm{w}}\right)$ & $0.59 \pm 0.01^{\mathrm{a}}$ & $0.56 \pm 0.00^{\mathrm{b}}$ & $0.54 \pm 0.00^{\mathrm{c}}$ & $0.42 \pm 0.00^{\mathrm{d}}$ \\
\hline \multirow{2}{*}{ Parameters } & \multicolumn{4}{|c|}{ Blends (FF:WF) for biscuit production } \\
\hline & $0: 100$ & $5: 95$ & 10:90 & $15: 85$ \\
\hline Wet gluten $(\%)$ & $23.5 \pm 0.72^{\mathrm{a}}$ & $21.2 \pm 0.21^{\mathrm{a}}$ & $20.2 \pm 0.10^{\mathrm{a}}$ & $19.2 \pm 0.15^{\mathrm{a}}$ \\
\hline Falling number (sec.) & $221.3 \pm 1.53^{\mathrm{a}}$ & $212.0 \pm 1.00^{\mathrm{b}}$ & $205.0 \pm 1.00^{\mathrm{c}}$ & $188.0 \pm 1.00^{\mathrm{d}}$ \\
\hline Water activity $\left(\mathrm{a}_{\mathrm{w}}\right)$ & $0.58 \pm 0.01^{\mathrm{a}}$ & $0.56 \pm 0.00^{\mathrm{b}}$ & $0.53 \pm 0.00^{\mathrm{c}}$ & $0.41 \pm 0.01^{\mathrm{d}}$ \\
\hline
\end{tabular}

All values are means of triplicates $\pm \mathrm{SD}, \mathrm{FF}$ - fenugreek flour, WF- wheat flour,

Levels not connected by same letter under the same rows are differed significant

Table 2. Functional properties of Wheat and blended flours for bread and biscuit production.

\begin{tabular}{llllll}
\hline FF:WF for Bread & Bulk density $\left(\mathbf{g} / \mathbf{c m}^{3}\right)$ & Water absorption $(\%)$ & Oil absorption(ml/g) & Dispersibility (\%) & Foaming capacity \\
\hline Control & $0.82 \pm 0.01^{\mathrm{a}}$ & $56.7 \pm 0.15^{\mathrm{a}}$ & $84.37 \pm 0.12^{\mathrm{a}}$ & $73.93 \pm 0.11^{\mathrm{a}}$ & $13.20 \pm 0.20^{\mathrm{c}}$ \\
$5: 95$ & $0.81 \pm 0.00^{\mathrm{b}}$ & $71.63 \pm 0.32^{\mathrm{b}}$ & $109.3 \pm 0.30^{\mathrm{b}}$ & $74.47 \pm 0.15^{\mathrm{b}}$ & $14.63 \pm 1.1^{\mathrm{b}}$ \\
$10: 90$ & $0.81 \pm 0.00^{\mathrm{c}}$ & $86.23 \pm 0.23^{\mathrm{c}}$ & $110.6 \pm 0.21^{\mathrm{c}}$ & $78.30 \pm 0.26^{\mathrm{c}}$ & $17.27 \pm 0.06^{\mathrm{a}}$ \\
$15: 85$ & $0.83 \pm 0.00^{\mathrm{c}}$ & $96.63 \pm 0.21^{\mathrm{d}}$ & $112.1 \pm 0.23^{\mathrm{d}}$ & $75.23 \pm 0.21^{\mathrm{d}}$ & $18.03 \pm 0.32^{\mathrm{a}}$ \\
FF:WF for Biscuit & Bulk density $\left(\mathrm{g} / \mathrm{cm}^{3}\right)$ & Water absorption $(\%)$ & Oil absorption $(\mathrm{ml} / \mathrm{g})$ & Dispersibility (\%) & Foaming capacity \\
Control & $0.82 \pm 0.01^{\mathrm{a}}$ & $58.00 \pm 0.30^{\mathrm{a}}$ & $85.47 \pm 0.11^{\mathrm{a}}$ & $73.93 \pm 0.11^{\mathrm{a}}$ & $12.04 \pm 0.64^{\mathrm{a}}$ \\
$5: 95$ & $0.77 \pm 0.01^{\mathrm{b}}$ & $74.03 \pm 0.25^{\mathrm{b}}$ & $110.5 \pm 0.10^{\mathrm{b}}$ & $78.77 \pm 0.25^{\mathrm{b}}$ & $14.13 \pm 0.15^{\mathrm{b}}$ \\
$10: 90$ & $0.78 \pm 0.00^{\mathrm{b}}$ & $81.93 \pm 0.11^{\mathrm{c}}$ & $111.5 \pm 0.50^{\mathrm{c}}$ & $75.33 \pm 0.15^{\mathrm{c}}$ & $15.40 \pm 0.36^{\mathrm{c}}$ \\
$15: 85$ & $0.79 \pm 0.00^{\mathrm{c}}$ & $96.23 \pm 0.50^{\mathrm{d}}$ & $112.73 \pm 012^{\mathrm{d}}$ & $76.00 \pm 0.00^{\mathrm{d}}$ & $17.52 \pm 0.19^{\mathrm{d}}$ \\
\hline
\end{tabular}

All values are means of triplicates $\pm \mathrm{SD}$; FF: fenugreek flour; WF: wheat flour; Levels not connected by same letter under the same rows differed significantly 
Table 3. Farinograph values of blended flours for bread production.

\begin{tabular}{lllll}
\hline \multirow{2}{*}{ Parameters } & Blends (FF:WF) & & & \\
\cline { 2 - 5 } & Wheat flour & $\mathbf{5 : 9 5}$ & $\mathbf{1 0 : 9 0}$ & $\mathbf{1 5 : 8 5}$ \\
\hline Consistency, FU & 455 & 447 & 431 & 418 \\
Water absorption(corrected for 500 FU) & 56.9 & 67.4 & 65.1 & 63.0 \\
Water absorption (corrected to 14.0\%) & 55.8 & 66.3 & 63.9 & 61.8 \\
Dough stability (min.) & 5.9 & 7.0 & 9.0 & 10.5 \\
Dough development time (min) & 4.2 & 4.5 & 6.1 & 7.5 \\
Degree of softening (FU) & 18 & 31 & 47 & 55 \\
Degree of softening (ICC),FU & 55 & 65 & 76 & 84 \\
Farinograph Quality Number & 66 & 76 & 100 & 123 \\
\hline
\end{tabular}

Where: FF-Fenugreek flour, WF-wheat flour Farinograph quality number

Table 4. Nutritional profile of bread made from different blends of fenugreek and wheat flour.

\begin{tabular}{|c|c|c|c|c|}
\hline \multirow{2}{*}{ Components } & \multicolumn{4}{|c|}{ Blends (FF:WF) } \\
\hline & 0:100 & $5: 95$ & $10: 90$ & $15: 85$ \\
\hline Moisture, $\%$ & $30.09 \pm 0.01^{\mathrm{a}}$ & $30.20 \pm 0.005^{\mathrm{a}}$ & $31.57 \pm 0.568^{\mathrm{b}}$ & $35.54 \pm 0.006^{\mathrm{C}}$ \\
\hline Protein, $\%$ & $10.85 \pm 0.006^{\mathrm{d}}$ & $11.78 \pm 0.015^{\mathrm{c}}$ & $12.76 \pm 0.021^{\mathrm{b}}$ & $13.66 \pm 0.025^{\mathrm{a}}$ \\
\hline Fiber,\% & $0.65 \pm 0.02^{\mathrm{a}}$ & $1.90 \pm 0.115^{\mathrm{b}}$ & $2.93 \pm 0.071^{\mathrm{c}}$ & $3.08 \pm 0.021^{\mathrm{d}}$ \\
\hline Ash, $\%$ & $1.85 \pm 0.01^{\mathrm{a}}$ & $2.06 \pm 0.042^{\mathrm{b}}$ & $2.56 \pm 0.105^{\mathrm{c}}$ & $2.97 \pm 0.072^{\mathrm{d}}$ \\
\hline Fat, \% & $1.61 \pm 0.076^{\mathrm{a}}$ & $1.94 \pm 0.01 \mathrm{a}$ & $1.97 \pm 0.01 \mathrm{a}$ & $2.11 \pm 0.182^{\mathrm{b}}$ \\
\hline Carbohydrate, $\%$ & $65.59 \pm 0.078^{\mathrm{a}}$ & $64.02 \pm 0.049^{\mathrm{b}}$ & $61.48 \pm 0.125^{\mathrm{c}}$ & $55.72 \pm 0.135^{\mathrm{d}}$ \\
\hline Energy (Kcal/100gm) & $320.32 \pm 0.379^{\mathrm{a}}$ & $320.66 \pm 0.221^{\mathrm{a}}$ & $314.66 \pm 0.510^{b}$ & $296.510 \pm 1.133^{\mathrm{c}}$ \\
\hline \multicolumn{5}{|l|}{ Minerals (mg/100g) } \\
\hline Calcium & $64.13 \pm 0.007^{\mathrm{d}}$ & $68.47 \pm 0.007^{c}$ & $73.99 \pm 0.014^{\mathrm{b}}$ & $78.04 \pm 0.021^{\mathrm{a}}$ \\
\hline Magnesium & $21.22 \pm 0.007^{\mathrm{a}}$ & $29.68 \pm 0.007^{\mathrm{b}}$ & $35.44 \pm 0.007^{\mathrm{c}}$ & $41.99 \pm 0.021^{\mathrm{d}}$ \\
\hline Iron & $7.79 \pm 0.014^{\mathrm{d}}$ & $7.84 \pm 0.007^{\mathrm{c}}$ & $7.99 \pm 0.014^{b}$ & $8.03 \pm 0.007^{\mathrm{a}}$ \\
\hline Zinc & $2.15 \pm 0.007^{\mathrm{a}}$ & $2.24 \pm 0.007^{\mathrm{b}}$ & $2.36 \pm 0.007^{\mathrm{c}}$ & $2.44 \pm 0.007^{\mathrm{d}}$ \\
\hline
\end{tabular}

All values are means of triplicates \pm SD; FF: fenugreek flour; WF: wheat flour; Levels not connected by same letter under the same row differed significantly

Table 5. Nutritional profile of biscuit made from different blends of fenugreek and wheat flour.

\begin{tabular}{|c|c|c|c|c|}
\hline \multirow{2}{*}{ Components } & \multicolumn{4}{|c|}{ Blends (FF:WF) } \\
\hline & $0: 100$ & $5: 95$ & $10: 90$ & $15: 85$ \\
\hline Moisture, $\%$ & $3.98 \pm 0.01^{\mathrm{a}}$ & $4.13 \pm 0.01^{\mathrm{b}}$ & $4.18 \pm 0.02^{\mathrm{c}}$ & $4.37 \pm 0.01^{\mathrm{d}}$ \\
\hline Protein, $\%$ & $9.66 \pm 0.05^{d}$ & $11.84 \pm 0.01^{\mathrm{c}}$ & $11.92 \pm 0.02^{\mathrm{b}}$ & $12.67 \pm 0.01^{\mathrm{a}}$ \\
\hline Fiber, $\%$ & $0.52 \pm 0.02^{\mathrm{c}}$ & $1.83 \pm 0.11^{\mathrm{b}}$ & $1.94 \pm 0.08^{\mathrm{b}}$ & $2.31 \pm 0.28^{\mathrm{a}}$ \\
\hline Ash, $\%$ & $1.25 \pm 0.01^{\mathrm{c}}$ & $2.40 \pm 0.20^{\mathrm{b}}$ & $3.59 \pm 0.12^{\mathrm{a}}$ & $3.78 \pm 0.18^{\mathrm{a}}$ \\
\hline Fat, $\%$ & $17.02 \pm 0.02^{\mathrm{a}}$ & $16.07 \pm 0.03^{b}$ & $15.67 \pm 0.22^{\mathrm{c}}$ & $13.64 \pm 0.28^{\mathrm{d}}$ \\
\hline Carbohydrate, $\%$ & $68.09 \pm 0.06^{\mathrm{a}}$ & $65.56 \pm 0.17^{\mathrm{b}}$ & $64.65 \pm 0.11^{\mathrm{c}}$ & $65.54 \pm 0.13^{\mathrm{b}}$ \\
\hline \multicolumn{5}{|l|}{ Minerals (mg/100g) } \\
\hline Calcium & $56.82 \pm 0.304^{\mathrm{a}}$ & $62.40 \pm 0.141^{\mathrm{b}}$ & $66.31 \pm 0.141^{\mathrm{c}}$ & $70.71 \pm 0.396^{\mathrm{d}}$ \\
\hline Magnesium & $19.78 \pm 0.689^{d}$ & $26.18 \pm 0.262^{\mathrm{c}}$ & $31.61 \pm 0.066^{\mathrm{b}}$ & $38.66 \pm 0.169^{a}$ \\
\hline Iron & $5.71 \pm 0.134^{\mathrm{c}}$ & $6.15 \pm 0.071^{\mathrm{b}}$ & $6.80 \pm 0.028^{\mathrm{a}}$ & $6.81 \pm 0.00^{\mathrm{a}}$ \\
\hline Zinc & $1.65 \pm 0.00^{\mathrm{a}}$ & $1.87 \pm 0.007^{\mathrm{b}}$ & $1.85 \pm 0.00^{\mathrm{c}}$ & $2.01 \pm 0.007^{\mathrm{d}}$ \\
\hline
\end{tabular}

All values are means of triplicates \pm SD; FF - fenugreek flour, WF- wheat flour. Levels not connected by same letter under the same row are significantly different

Table 6. Physical characteristics of bread and biscuit supplemented with fenugreek flour.

\begin{tabular}{llll}
\hline Bread samples (FF:WF) & Loaf volume $(\mathbf{m l})$ & Loaf weight $(\mathbf{g})$ & Specific loaf volume $(\mathbf{m l} / \mathbf{g})$ \\
\hline Control & $428.00 \pm 2.00^{\mathrm{a}}$ & $86.66 \pm 0.14^{\mathrm{a}}$ & $4.94 \pm 0.03^{\mathrm{a}}$ \\
$5: 95$ & $408.33 \pm 2.08^{\mathrm{b}}$ & $90.98 \pm 0.77^{\mathrm{b}}$ & $4.49 \pm 0.04^{\mathrm{b}}$ \\
$10 ; 90$ & $391.67 \pm 3.79^{\mathrm{c}}$ & $93.29 \pm 0.61^{\mathrm{c}}$ & $4.18 \pm 0.03^{\mathrm{c}}$ \\
15:95 & $334.67 \pm 1.53^{\mathrm{d}}$ & $94.73 \pm 0.11^{\mathrm{d}}$ & $3.53 \pm 0.02^{\mathrm{d}}$ \\
Biscuit samples (FF:WF) & Width(diameter),(mm) & Thickness, (mm) & Spread Ratio (D/T) \\
Control & $66.40^{ \pm} 0.10^{\mathrm{a}}$ & $6.71^{ \pm} 0.05^{\mathrm{d}}$ & $98.95^{ \pm} 2.0^{\mathrm{a}}$ \\
5:95 & $65.47^{ \pm} 0.06^{\mathrm{b}}$ & $7.10^{ \pm} 0.06^{\mathrm{c}}$ & $92.21^{ \pm} 1.00^{\mathrm{b}}$ \\
$10: 90$ & $65.00^{ \pm} 0.00^{\mathrm{c}}$ & $7.84^{ \pm} 0.12^{\mathrm{b}}$ & $82.90^{ \pm} 0.01^{\mathrm{c}}$ \\
$15: 85$ & $64.40^{ \pm} 0.14^{\mathrm{d}}$ & $8.64^{ \pm} 0.01^{\mathrm{a}}$ & $74.54^{ \pm} 0.12^{\mathrm{d}}$ \\
\hline
\end{tabular}

All values are means of triplicates $\pm \mathrm{SD}$, FF: fenugreek flour, WF: wheat flour. Levels not connected by same letter under the same column differed significantly 
Table 7. Sensory characteristics of breads supplemented with germinated fenugreek flour.

\begin{tabular}{|c|c|c|c|c|}
\hline \multirow{2}{*}{ Sensory attributes } & \multicolumn{4}{|c|}{ Blends (FF:WF) } \\
\hline & Control & $5: 95$ & $10: 90$ & $15: 85$ \\
\hline Crust Color & $8.13 \pm 0.32^{\mathrm{a}}$ & $7.97 \pm 0.06^{\mathrm{a}}$ & $7.77 \pm 0.35^{\mathrm{a}}$ & $5.04 \pm 0.36^{b}$ \\
\hline Aroma (odor) & $7.76 \pm 0.32^{\mathrm{a}}$ & $7.87 \pm 0.11^{\mathrm{a}}$ & $7.53 \pm 0.06^{\mathrm{a}}$ & $5.1 \pm 0.10^{b}$ \\
\hline Taste & $7.80 \pm 0.20^{\mathrm{a}}$ & $7.23 \pm 0.23^{\mathrm{ab}}$ & $7.03 \pm 0.64^{\mathrm{b}}$ & $4.46 \pm 0.15^{\mathrm{c}}$ \\
\hline Appearance & $7.70 \pm 0.36^{\mathrm{a}}$ & $7.27 \pm 0.47^{\mathrm{a}}$ & $7.23 \pm 0.21^{\mathrm{a}}$ & $5.40 \pm 0.53^{b}$ \\
\hline Texture & $8.30 \pm 0.10^{\mathrm{a}}$ & $7.89 \pm 0.11^{\mathrm{a}}$ & 7. $83 \pm 0.40^{\mathrm{a}}$ & $6.53 \pm 0.32^{b}$ \\
\hline Overall acceptability (OAA) & $8.10 \pm 0.10^{\mathrm{a}}$ & $7.93 \pm 0.23^{\mathrm{a}}$ & $7.73 \pm 0.38^{\mathrm{a}}$ & $4.46 \pm 0.15^{\mathrm{b}}$ \\
\hline
\end{tabular}

W: wheat flour, FF: germinated fenugreek flour; Levels not connected by same letter under the same rows are significantly different.

Table 8. Microbiological analysis of bread and biscuit supplemented with fenugreek flour.

\begin{tabular}{|c|c|c|c|c|}
\hline \multirow{2}{*}{ Microbial counts } & \multicolumn{4}{|c|}{ Microbial load of samples (cfu/g) } \\
\hline & $\mathbf{F B}_{\mathbf{C}}$ & $\mathrm{FBr}_{10}$ & $\mathbf{F B i}_{\mathbf{C}}$ & $\mathbf{F B i}_{5}$ \\
\hline TPC & $1.3 \times 10^{3}$ & $1.8 \times 10^{2}$ & $9.5 \times 10^{2}$ & $1.2 \times 10^{3}$ \\
\hline Coliforms count & ND & ND & ND & ND \\
\hline E.coli count & ND & ND & ND & ND \\
\hline Yeast count & ND & ND & ND & ND \\
\hline
\end{tabular}

TPC: Total plate count; $\mathrm{FB}_{\mathrm{C}}$ : bread control; $\mathrm{FBr}_{10}$ bread with $10 \%$ fenugreek flour; $\mathrm{FBi}_{\mathrm{C}}$ : biscuit control, $\mathrm{FBi}_{5}$ biscuit with $5 \%$ fenugreek flour; ND-Not detected.

\section{Conclusion}

Composite blends of germinated fenugreek seed flour supplemented with wheat flour exhibited desirable physicochemical and functional characteristics which resulted acceptable bread and biscuit. The farinograph analysis showed that the supplementation of wheat flour with fenugreek flour was satisfactory in producing better flour for bread production. However, the gluten content decreased with increasing proportion of fenugreek flour. The protein, fiber and ash as well as minerals content of products increased as a result of the addition of fermented fenugreek flour. The research work has explored the utilization of fenugreek flour by supplementing with wheat flour for the preparation of bread and biscuit. The sensory evaluation of products has exhibited that 5 and $10 \%$ for bread and $5 \%$ for biscuit, fermented fenugreek flour supplemented with wheat flour resulted highly acceptable bread and biscuit at par with control samples.

\section{References}

[1] Addisu K. 2011. Optimization of Extrusion conditions for Developing Ready-to-Eat defatted soy-rice and chocolate blend extrudate. M.Sc. thesis. Addis Ababa Institute of Technology, Addis Ababa University, Ethiopia.

[2] Agrawal S R. 1990. Prospects for small-scale biscuit industry in the nineties. Indian Food Industry 19-21:22.

[3] Ajanaku K O, Ajanaku C O, Edobour-OsohA, Nwinyi O C. 2012. Nutritive value of Sorghum Ogi fortified with groundnut seed (Arachis hypogaea L.). Am. J. Food Technol 79:82-88.

[4] AOAC 2000. Official methods of Analysis. 17th edn. Association of Official Analytical Chemists. Washington DC
[5] Bolandi F, Shahidi N, Sedaghat R F, H Mousavi-Nik 2008. Shelf-life Determination of Saffron Stigma Water Activity and Temperature Studies World Applied Sciences Journal 5: 132136

[6] Coffman, C.W. and Garcia, V.V. 1977. Functional properties and amino acid content of a protein isolate from mung bean flour. J. Food Technology (U.K.) 12:473.

[7] Etana L, Y K Jha, S A Emire. 2013. Development and Evaluation of Value Added bread made By supplementation of defatted rice bran to Wheat flour. J. Beverage and Food World 40:11-14.

[8] Fretzdarff B, Brummer J M 1992. Reduction of phytic acid during bread-making of whole eal bread, Cereal Chem 69: 266-270.

[9] Gall, Alevtina, and Zerihun S. (2009). Ethiopian Traditional and Herbal Medications and their Interactions with Conventional Drugs. EthnoMed. University of Washington. Retrieved on october 13, 2011.

[10] Hegazy AI, Ibrahim MI. 2009. Evaluation of the nutritional protein quality of wheat biscuit supplemented by fenugreek seed flour. W. J. Dairy Food Sci 4:129-135.

[11] Helen W. 2011. Influence of processing on antinutrients and production of some value added finger millet based products. Msc thesis. Addis Ababa Institute of Technology, Addis Ababa University. Ethiopia.

[12] McWatters KH, Ouedraogo J B, Resurreccion YC Hung, DR. 2003. Physical and sensory characteristics of sugar cookies containing mixtures of wheat, fonio (Digitaria exilis) and cowpea (Vigna unguiculata) flours. Int. J. Food Sci. Technol 38: $403-410$

[13] Meilgaard M C, Civille G V, Carr B T 2007. Sensory Evaluation Techniques, 4th edn. Boca Raton: CRC Press.

[14] Narayana K, Narasinga Rao M S 1984. Effect of partial hydrolysis on winged bean flours. J Food Sci 49:944-947. 
[15] Neilsen S S 2003. Food analysis Laboratory manual. Springer Science, U.S.A.

[16] Oladipo F Y, Nwokocha L M 2011. Effect of Sida acuta and Corchorus olitorius Mucilages on the Physicochemical Properties of Maize and Sorghum Starches. Asian J.Applied Sci 4:514-525.

[17] Rao H P, Hemamalini R 1991. Effect of incorporating wheat bran on reheological characteristic and bread making quality of flour. J. Food. Sci. Technol 28: 92-97.

[18] Rosell C M, Rojas J A, Benedito C 2001. Influence of hydrocolloids on dough rheology and bread quality. Food Hydrocolloids 15: 75-81

[19] Shalini H, Sudesh J. 2002. Effect of soaking and germination on nutrient and antinutrient contents of fenugreek (trigonella foenum graecum 1.) J of Food. Bioch 27: 165-176.

[20] Shalini H, Sudesh J. 2003. Physicochemical, rheological, and organoleptic characteristics of wheat-fenugreek supplemented blends. Nahrung/Food $265-268$.

[21] Shalini H, Sudesh J. 2004. Nutritional Evaluation of WheatFenugreek Blends for Product Making. Plant Foods for Human Nutrition 59: 149-154.
[22] Shalini H, Sudesh J. 2005. Effect of fenugreek flour blending on physical, organoleptic and chemical characteristics of wheat bread. Nutrition \& Food Science 35: 229-242.

[23] Sharma H R, Chauhan G S. 2000. Physical, sensory and chemical characteristics of wheat breads supplemented with fenugreek. Journal Food Science 37: 91-94.

[24] Sharma R.D, Raghuram T C, Rao N S. 1996. Effect of fenugreek seeds on blood glucose and serum lipids in type I diabetes. Eur. J. Clin. Nutr 44: 301-306.

[25] Stark A, Madar Z. 1993. The effect of ethanol extract derived from fenugreek on bile acid absorption and cholesterol levels in rats. Br J. Nutr. Jan $69:$ 277-37.

[26] Toufeili I. 1999. The role of gluten proteins in the baking of Arabic Bead. J. Cereal Science 30:255 - 265.

[27] Tizazu S, Urga K, Abuye C, Retta N.2010. Improvement of energy and nutrient density of sorghum based complementary foods using germination. African journal of food agriculture nutrition and development 10: 2928-2942.

[28] WHO. 1994. Guideline value for food and drinking water, World Health Organization Geneva: 3-4. 